\title{
Effect of TGF- $\beta$ on Gli2 expression in HL60 and U937 cell lines
}

\author{
ZHE LI ${ }^{1,2}$, DENG PAN ${ }^{1}$ and YAN LI ${ }^{1}$ \\ ${ }^{1}$ Department of Hematology, The First Affiliated Hospital, China Medical University, \\ Shenyang, Liaoning 110001, P.R. China
}

Received December 27, 2011; Accepted February 23, 2012

DOI: $10.3892 / \mathrm{mmr} .2012 .820$

\begin{abstract}
The Hedgehog (Hh) signaling pathway is involved in a variety of tumor-related diseases, including leukemia. The aim of this study was to determine whether there is an interaction between the Hh signaling pathway and transforming growth factor- $\beta$ (TGF- $\beta$ ) in the HL60 and U937 cell lines. HL60 and U937 cells were treated with TGF- $\beta$, tumor necrosis factor- $\alpha$ (TNF- $\alpha$ ) and specific inhibitor of Smad3 (SIS3). The expression of Gli2 was detected by real-time PCR and western blotting. The results showed that TGF- $\beta$ alone did not affect the Gli2 expression in HL60 cells, while it significantly reduced the level of Gli2 expression in U937 cells. TGF- $\beta+$ TNF- $\alpha$ reduced the expression of Gli2 in HL60 cells and U937 cells. The reduction in the level of Gli2 expression in U937 cells by TGF- $\beta+$ TNF- $\alpha$ was greater than that caused by TGF- $\beta$ alone. SIS 3 inhibited the effect of TGF- $\beta$. Our results suggest that the effect on Gli2 expression in HL60 and U937 cells induced by TGF- $\beta$ is Smad3-dependent and independent of Hh receptor signaling.
\end{abstract}

\section{Introduction}

The Hedgehog (Hh) signaling pathway is associated with cell growth and differentiation, with a normal role in embryonic pattern formation and adult tissue homeostasis and pathological roles in tumor initiation and growth (1). Gli transcription factors are the final effectors of the Hh signaling pathway. In a number of tumors, including those of the pancreas, prostate, skin and lung, the ectopic activation of Gli proteins has been linked to tumorigenesis (2). Evidence suggests additional, non-canonical mechanisms of Gli activation (2). Certain studies

Correspondence to: Professor Yan Li, Department of Hematology, The First Affiliated Hospital, China Medical University, No. 155 Nanjing Street, Heping, Shenyang, Liaoning 110001, P.R. China

E-mail: liyan2@medmail.com.cn

Present address: ${ }^{2}$ Department of Hematology, The First Affiliated Hospital, Liaoning Medical College, No.2, Segment 5, Renmin Street, Guta, Jinzhou, Liaoning 121001, P.R. China

Key words: Gli2, transforming growth factor- $\beta$, tumor necrosis factor- $\alpha$, specific inhibitor of Smad3 have suggested that in normal fibroblasts and keratinocytes, as well as in various cancer cell lines, the Gli transcription factors are not solely regulated by $\mathrm{Hh} / \mathrm{Smo}$ signaling, but also by other pathways, including the transforming growth factor- $\beta$ (TGF- $\beta$ ) signaling pathway. TGF- $\beta$ induces Gli2 expression in a Smad3-dependent manner and this effect is independent from the Patched/Smoothened (Ptch/Smo) axis (3).

In hematopoiesis, Hh family members are also significant in the regulation of stem/progenitor cell expansion in vitro and in vivo (4). The components of Hh signaling have been detected in several leukemia cell lines; Ptch and Smo were expressed in Jurkat cells (5), Shh and Gli1 in HL60 and KG-1 cells (6) and Gli2 in U937 and HL60 cells (7). Similar to Hh members, TGF- $\beta$ is involved in regulating the balance between proliferation and differentiation in hematopoietic cells $(8,9)$.

To find a new target for leukemia treatment, we hypothesized that there is also crosstalk between the Hh signaling pathway and TGF- $\beta$ in leukemia cells. In this study, we examined the ability of TGF- $\beta$ to modulate the expression of the Hh signaling molecule Gli2 in the HL60 and U937 cell lines. Targeting the interaction between Hh and TGF- $\beta$ signaling may provide new therapeutic opportunities for leukemia treatment.

\section{Materials and methods}

Cell cultures and reagents. The human myeloid leukemia cell lines HL60 and U937 were gifts from the Institute of Hematology (Chinese Academy of Medical Sciences, Beijing, China). The cells were cultured in RPMI-1640 supplemented with $10 \%$ heat-inactivated fetal calf serum (FCS), $2 \mathrm{mM} / 1$ L-glutamine, $0.1 \%$ penicillin $(100 \mathrm{U} / \mathrm{ml})$ and streptomycin $(100 \mathrm{mg} / \mathrm{ml})$ at $37^{\circ} \mathrm{C}$ in a humidified atmosphere of $5 \% \mathrm{CO}_{2}$. When required, HL60 and U937 cells were seeded in starving medium (containing $2.5 \%$ FCS) at the same cell density $\left(2 \times 10^{5}\right.$ cells $\left./ \mathrm{ml}\right)$. The cells were treated with human recombinant TGF- $\beta 1$ ( $5 \mathrm{ng} / \mathrm{ml}$; referred to as TGF- $\beta$ ), tumor necrosis factor- $\alpha$ (TNF- $\alpha ; 5 \mathrm{ng} / \mathrm{ml})$ and/or specific inhibitor of Smad3 (SIS3; $5 \mu \mathrm{M})$. TGF- $\beta 1$ and TNF- $\alpha$ were purchased from Peprotech, Inc. (Rocky Hill, NJ, USA). SIS3 was purchased from Merck (Darmstadt, Germany). The Gli2 monoclonal antibody was purchased from Santa Cruz Biotechnology, Inc. (Santa Cruz, CA, USA).

RT-PCR and real-time PCR. Total RNA was extracted using an RNeasy mini kit (Qiagen, Hilden, Germany). RNA $(1 \mu \mathrm{g})$ was reverse-transcribed by SuperScript ${ }^{\mathrm{TM}}$ II (Invitrogen 


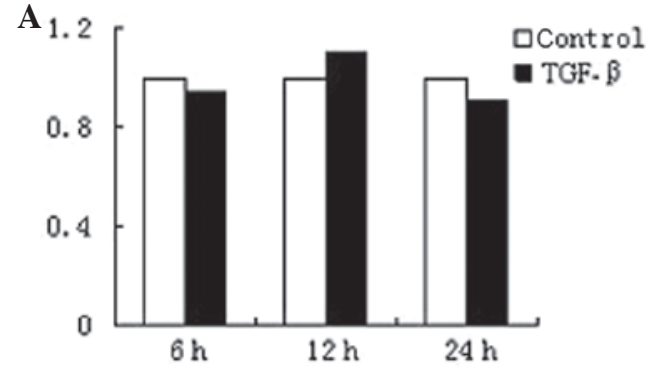

C

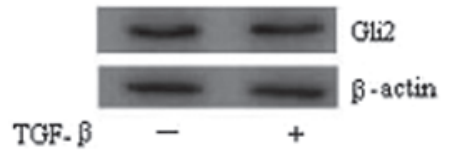

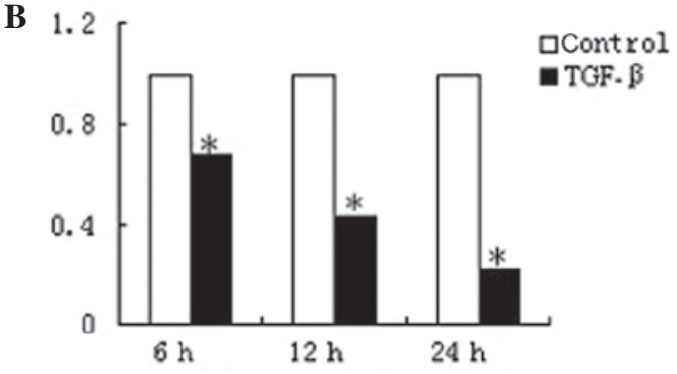

D

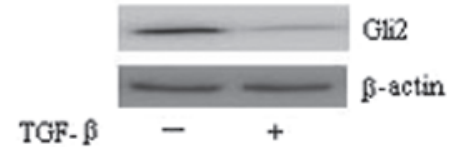

Figure 1. Effect of TGF- $\beta$ on Gli2 expression in HL60 and U937 cells. (A) Effect of $5 \mathrm{ng} / \mathrm{ml} \mathrm{TGF-} \beta 1$ on Gli2 mRNA in HL60 cells for 6,12 and $24 \mathrm{~h}$. (B) Effect of $5 \mathrm{ng} / \mathrm{ml}$ TGF- $\beta 1$ on Gli2 mRNA in U937 cells for 6, 12 and $24 \mathrm{~h}$. (C) Effect of $5 \mathrm{ng} / \mathrm{ml} \mathrm{TGF- \beta 1} \mathrm{on} \mathrm{Gli2} \mathrm{protein} \mathrm{in} \mathrm{HL60} \mathrm{cells} \mathrm{for} 24 \mathrm{~h}$. (D) Effect of $5 \mathrm{ng} / \mathrm{ml}$ TGF- $\beta 1$ on Gli2 protein in U937 cells for $24 \mathrm{~h}$. "P<0.05, treatment group vs. control group. TGF- $\beta$, transforming growth factor- $\beta$.

Japan K.K., Tokyo, Japan). Reverse transcription was performed using genomic DNA-free RNA with a random primer. The RT-PCR assays were carried out in the GeneAmp PCR System 9700. Real-time PCR was subsequently performed using SYBR-Green core PCR reagents (Rotor-Gene 6000) to quantify the Gli2 mRNA steady-state levels. The expression of the housekeeping gene ABL was used as a control. Each assay was repeated three times. The final results were compared using the comparative $\Delta \Delta \mathrm{Ct}$ method. The primer pairs for Gli2 (5'-TGGCCGCTTCAGATGACAGATGTTG-3' and 5'-CGTTAGCCGAATGTCAGCCGTGAAG-3') and ABL (5'-CGAGAGCCTGGCCTACAACAA-3' and 5'-CTAG CAGCTCATACACCTGGGACA-3') were designed and synthesized by Takara. PCR amplification was carried out using 45 cycles of $95^{\circ} \mathrm{C}$ for $60 \mathrm{sec}, 95^{\circ} \mathrm{C}$ for $10 \mathrm{sec}$ and $60^{\circ} \mathrm{C}$ for $30 \mathrm{sec}$.

Western blot analyses. Following incubation, the cells were washed twice in ice-cold PBS after centrifugation at 1,000 rpm and $4^{\circ} \mathrm{C}$. The cells were immediately transferred to ice-cold lysis buffer and PMSF was added. The solution was agitated at $4^{\circ} \mathrm{C}$ for $30 \mathrm{~min}$. Cell extracts were then collected by centrifugation at $12,000 \mathrm{rpm}$ for $5 \mathrm{~min}$ at $4^{\circ} \mathrm{C}$ and the samples were immediately frozen at $-80^{\circ} \mathrm{C}$ until use. The samples were homogenized with a HEPES buffer. Protein (100 $\mu \mathrm{g} / \mathrm{lane})$ was separated by $10 \%$ SDS-PAGE and blotted onto PVDF membranes. The membranes were then blocked with T-TBS containing 5\% skimmed milk. The Gli2 protein content was detected with an anti-Gli2 antibody (Santa Cruz Biotechnology, Inc). An antibody against $\beta$-actin was used to verify that there was equal protein content in each sample. Following washing with T-TBS, the membranes were incubated with secondary antibodies. The membranes were detected with the chemiluminescence ECL western blotting system.

Statistical analysis. The gene expression levels in the HL60 and U937 cell lines were compared using one-way ANOVA. $\mathrm{P}<0.05$ was considered to indicate a statistically significant result. Results obtained from multiple experiments were reported as the mean \pm the standard error of the mean (SEM).

\section{Results}

Effect of TGF- $\beta$ on Gli2 expression is different in the HL60 and U937 cell lines. To determine whether TGF- $\beta$ affects Gli2 expression, groups of HL60 and U937 cells were incubated with and without TGF- $\beta$. No significant differences were found in the level of Gli2 mRNA in the HL60 cells between the control and TGF- $\beta$ groups (Fig. 1A). By contrast, significant reductions in the level of Gli2 mRNA in response to TGF- $\beta$ was observed in the U937 cells, emerging at $6 \mathrm{~h}$ and lasting for at least $24 \mathrm{~h}$ (Fig. 1B).

Western blot analysis revealed that there was no difference in the level of the Gli2 protein in the HL60 cells in the control and TGF- $\beta$ groups (Fig. 1C). However, the level of the Gli2 protein in U937 cells without TGF- $\beta$ was higher than that of the cells treated with TGF- $\beta$ (Fig. 1D).

Incubation with TGF- $\beta$ and TNF- $\alpha$ markedly reduced Gli2 expression in HL60 and U937 cells. To determine whether TNF- $\alpha$ affects Gli2 expression in HL60 and U937 cells, the cells were cultured with TNF- $\alpha$. No significant differences were found in the level of Gli2 mRNA in HL60 and U937 cells between the control and TNF- $\alpha$ groups from 12 to $48 \mathrm{~h}$ (Fig. 2A and B).

To study whether the combination of TGF- $\beta$ and TNF- $\alpha$ affects Gli2 expression in HL60 and U937 cells, the cells were cultured with TGF- $\beta$, with or without TNF- $\alpha$. For HL60 cells, the level of expression of Gli2 mRNA and protein in the TGF- $\beta+$ TNF- $\alpha$ group was found to be much lower than that in the control and TGF- $\beta$ groups, while no significant difference was observed between the latter two groups (Fig. 2C and E). For U937 cells, the level of expression of Gli2 mRNA and protein of the TGF- $\beta+\mathrm{TNF}-\alpha$ group was the lowest of the three groups and that of the TGF- $\beta$ group was lower than the control group (Fig. 2D and F).

Gli2 induction by TGF- $\beta$ is Smad3-dependent. To determine whether Gli2 induction by TGF- $\beta$ is Smad3-dependent, SIS3 (10) was used to treat the HL60 and U937 cells. The level of Gli2 mRNA and protein expression in HL60 cells decreased 
A

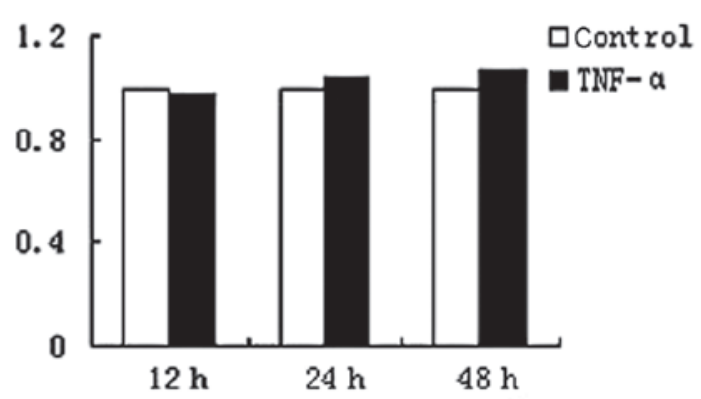

C

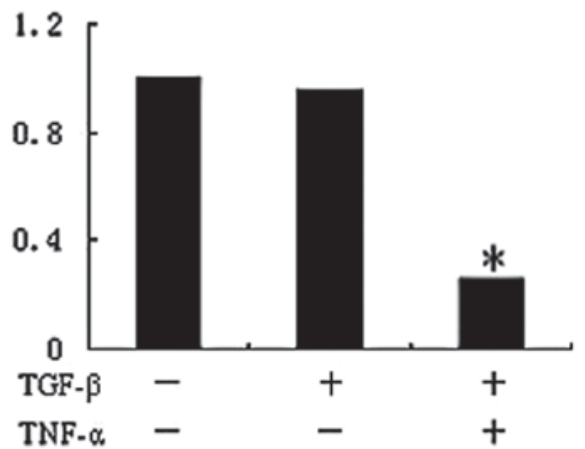

$\mathbf{E}$

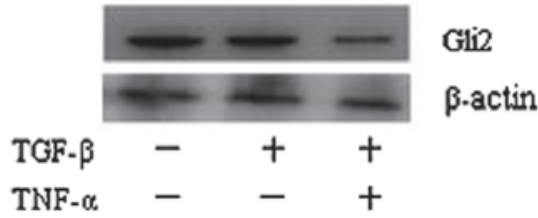

B

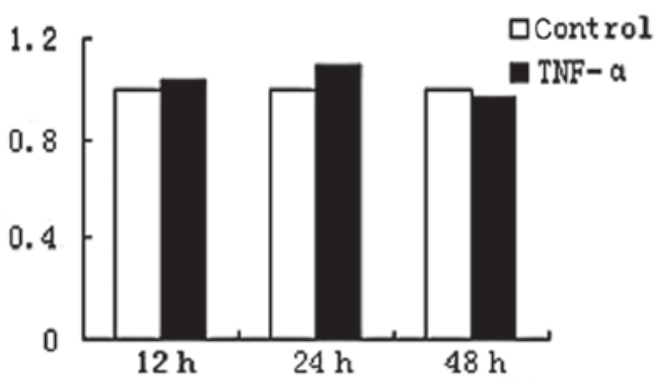

D

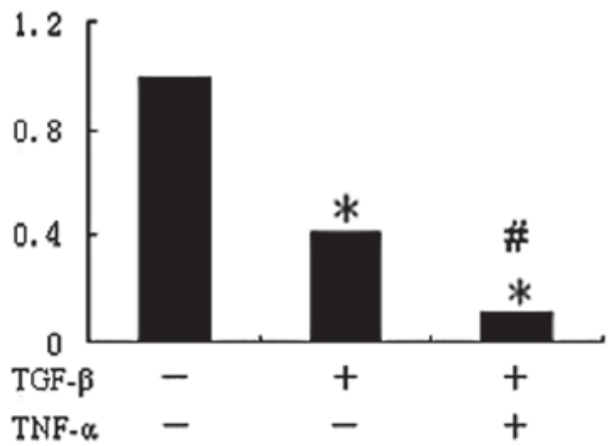

$\mathbf{F}$

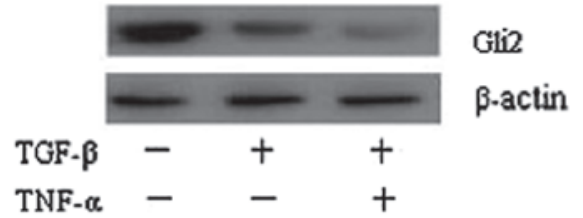

Figure 2. Effect of TGF- $\beta$ with or without TNF- $\alpha$ on Gli2 expression in HL60 and U937 cells is shown. (A) Effect of $5 \mathrm{ng} / \mathrm{ml}$ TNF- $\alpha$ on Gli2 mRNA in HL60 cells for 12, 24 and $48 \mathrm{~h}$. (B) Effect of $5 \mathrm{ng} / \mathrm{ml} \mathrm{TNF-} \alpha$ on Gli2 mRNA in U937 cells for 12, 24 and $48 \mathrm{~h}$. (C) Effect of $5 \mathrm{ng} / \mathrm{ml} \mathrm{TGF}-\beta 1 \mathrm{and} 5 \mathrm{ng} / \mathrm{ml} \mathrm{TNF}-\alpha$ on Gli2 mRNA in HL60 cells for $24 \mathrm{~h}$. (D) Effect of $5 \mathrm{ng} / \mathrm{ml}$ TGF- $\beta 1$ and $5 \mathrm{ng} / \mathrm{ml} \mathrm{TNF-} \alpha$ on Gli2 mRNA in U937 cells for $24 \mathrm{~h}$. (E) Effect of $5 \mathrm{ng} / \mathrm{ml} \mathrm{TGF}-\beta 1 \mathrm{and} 5 \mathrm{ng} / \mathrm{ml}$ TNF- $\alpha$ on Gli2 protein in HL60 cells for 24 h. (F) Effect of $5 \mathrm{ng} / \mathrm{ml}$ TGF- $\beta 1$ and $5 \mathrm{ng} / \mathrm{ml} \mathrm{TNF-} \alpha$ on Gli2 protein in U937 cells for $24 \mathrm{~h}$. "P<0.05, treatment group vs. control group. ${ }^{~} \mathrm{P}<0.05$, TGF- $\beta 1+\mathrm{TNF}-\alpha$ group vs. TGF- $\beta 1$ group. TGF- $\beta$, transforming growth factor- $\beta$; TNF- $\alpha$, tumor necrosis factor- $\alpha$.

A

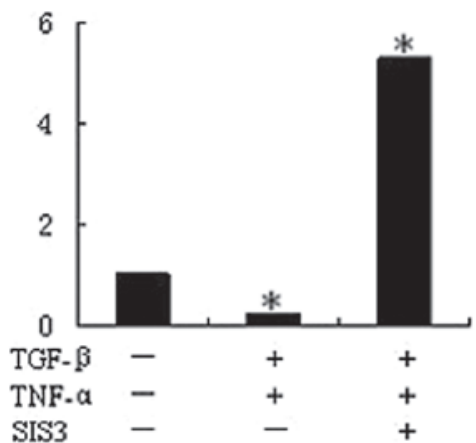

C

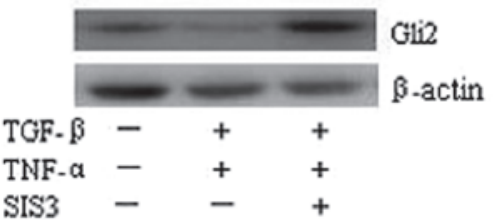

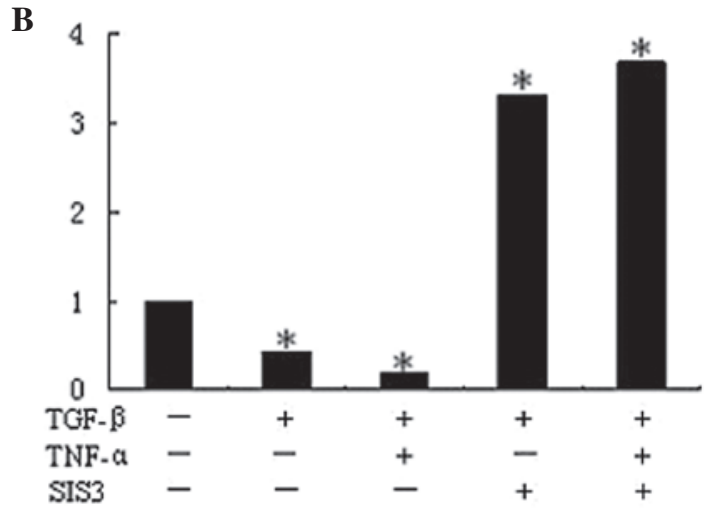

D

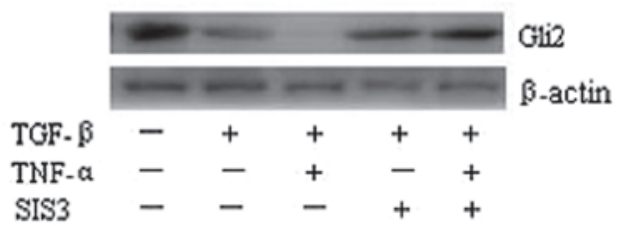

Figure 3. Effect of TGF- $\beta$ or TGF- $\beta+$ TNF- $\alpha$ with or without SIS3 on Gli2 expression in HL60 and U937 cells is shown. (A) Effect of $5 \mathrm{ng} / \mathrm{ml}$ TGF- $\beta 1,5 \mathrm{ng} / \mathrm{ml}$ TNF- $\alpha$ and $5 \mu \mathrm{M}$ SIS 3 on Gli2 mRNA in HL60 cells for 24 h. (B) Effect of $5 \mathrm{ng} / \mathrm{ml}$ TGF- $\beta 1,5 \mathrm{ng} / \mathrm{ml} \mathrm{TNF}-\alpha$ and $5 \mu$ M SIS3 on Gli2 mRNA in U937 cells for $24 \mathrm{~h}$. (C) Effect of $5 \mathrm{ng} / \mathrm{ml}$ TGF- $\beta 1,5 \mathrm{ng} / \mathrm{ml} \mathrm{TNF}-\alpha$ and $5 \mu \mathrm{M}$ SIS3 on Gli2 protein in HL60 cells for $24 \mathrm{~h}$. (D) Effect of $5 \mathrm{ng} / \mathrm{ml} \mathrm{TGF-} \beta 1,5 \mathrm{ng} / \mathrm{ml}$ TNF- $\alpha$ and $5 \mu \mathrm{M}$ SIS3 on Gli2 protein in U937 cells for $24 \mathrm{~h}$. "P<0.05, treatment group vs. control group. TGF- $\beta$, transforming growth factor- $\beta$; TNF- $\alpha$, tumor necrosis factor- $\alpha$; SIS3, specific inhibitor of Smad3. 
A

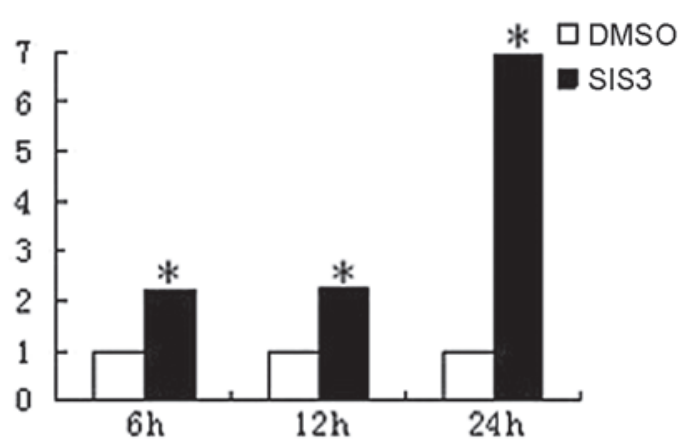

C

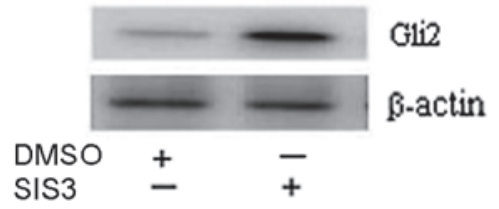

B

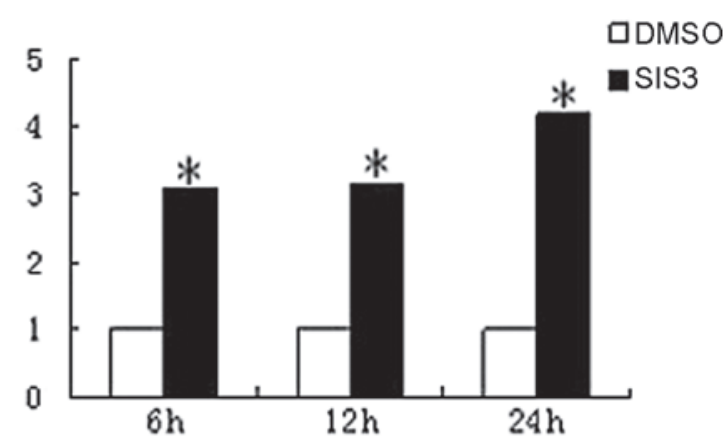

D

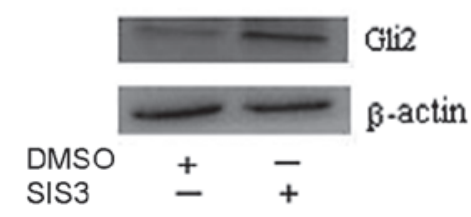

Figure 4. SIS3 increases Gli2 expression in HL60 and U937 cells. (A) Effect of $5 \mu \mathrm{M} \mathrm{SIS} 3$ on Gli2 mRNA in HL60 cells for 6, 12 and 24 h. (B) Effect of $5 \mu \mathrm{M}$ SIS3 on Gli2 mRNA in U937 cells for 6, 12 and 24 h. (C) Effect of $5 \mu \mathrm{M} \mathrm{SIS} 3$ on Gli2 protein in HL60 cells for 24 h. (D) Effect of $5 \mu \mathrm{M}$ SIS3 on Gli2 protein in U937 cells for 24 h. "P<0.05, SIS3 group vs. DMSO group. SIS3, specific inhibitor of Smad3.

when the cells were treated with TGF- $\beta+$ TNF- $\alpha$ and increased when treated with TGF- $\beta+$ TNF- $\alpha+$ SIS3 (Fig. 3A and C). The level of Gli2 mRNA and protein expression in the U937 cells decreased when the cells were treated with TGF- $\beta$ or TGF- $\beta+$ TNF- $\alpha$ and increased when the cells were treated with TGF- $\beta+$ SIS3 or TGF- $\beta+$ TNF- $\alpha+$ SIS3 (Fig. 3B and D).

SIS3 increases the level of Gli2 expression in HL60 and U937 cells. To determine whether TGF- $\beta$ secreted by HL60 and U937 cells affect the level of Gli2 expression, the cells were pretreated with SIS3 or DMSO (control). Fig. 4 shows that the level of expression of Gli2 mRNA and protein in HL60 (Fig. 4A and C) and U937 cells (Fig. 4B and D) was higher in the SIS3 than in the control group.

\section{Discussion}

Hh signaling is critical in vertebrate development, patterning and cell fate induction (11). Deregulation in Hh signaling, which regulates tissue patterning and stem-cell maintenance, is associated with different types of human cancer (12). The secreted protein $\mathrm{Hh}$ exerts its effects through binding to its receptor, Ptch, which blocks its inhibition of Smo, another transmembrane protein. This process activates downstream cytoplasmic transcription factors, for example the Ci protein in Drosophila or the mammalian homolog Gli proteins (1). This downstream signaling leads to the entry of the cell into the cell cycle (13), maintenance of self-renewal of stem cells in various tissues (14), inhibition of apoptosis (15), modulation of tissue polarity (16) and regulation of tissue stem cell differentiation (17).

There are three closely related Gli proteins: Gli1, Gli2 and Gli3 (18). Gli2 is thought to function upstream of Gli1 and to be the primary mediator of Hh signaling (19), inducing Gli1 expression via direct binding to its promoter region (20). Gli3 proteins are thought to inhibit the activating functions of all the coexpressed Gli genes (21).
Similar to $\mathrm{Hh}$ members, as a family of growth factors involved in various essential physiological processes, TGF- $\beta$ plays a complex role as a mediator in inflammation, tissue repair, angiogenesis and in the regulation of cell growth and differentiation $(22,23)$. TGF- $\beta$ binds to a heteromeric cellsurface complex of type I (T $\beta R I)$ and type II (T $\beta R I I)$ serine/ threonine kinase receptors (24). Following ligand binding, T $\beta R I I$ recruits and activates T $\beta R I$, which in turn phosphorylates Smad proteins. The receptor-associated Smad, Smad2 or Smad3, then forms a heteromer with Smad4 and later translocates into the nucleus, where it acts as a transcription factor to regulate the target gene expression $(25,26)$.

There are abundant data concerning the effects of TGF- $\beta$ on leukemia cells lines, including the inhibition of proliferation, induction of differentiation, altered expression of adhesion molecules and cytokine receptors, induction of apoptosis (27-29) and its acting as an inhibitory autocrine factor in the proliferation of leukemia cells (30). TGF- $\beta 1$ is thought to be a primary negative regulator of early hematopoiesis $(31,32)$.

$\mathrm{Hh}$ receptor molecules are lost in several leukemia cell lines, including U937 and HL60, but the Gli2 transcription factor is expressed (7). For these cells, the blockade of the autocrine loop in Hh signaling would not be possible. Therefore, Gli2 may be an alternative target for the treatment of acute myeloid leukemia (AML). One possible strategy is to use small interfering RNA (siRNA) specific for Gli2. However, the efficient transfer of siRNA into hematopoietic cells is problematic. We found that TGF- $\beta$ decreased the level of Gli2 expression in the U937 cell line and that TGF- $\beta$ combined with TNF- $\alpha$ decreased the level of Gli2 expression in the HL60 cell line. This suggests that TGF- $\beta$ is one of the signals that is involved in regulating the Gli2 gene in leukemia cell lines.

Treatment with TGF- $\beta$ did not significantly affect Gli2 expression in HL60 cells (Fig. 1A and C), but it significantly decreased Gli2 expression in U937 cells (Fig. 1B and D). It is possible that the expression level of the TGF- $\beta$ receptor 
was lower in HL60 compared to U937 cells (33); thus, adding TGF- $\beta$ did not affect the Gli2 expression in HL60 cells.

Previous studies have reported that treating HL60 and U937 cells with TNF- $\alpha$ induced a dose-dependent increase in the expression of TGF- $\beta$ receptors (33). The treatment of HL60 and U937 cells with combinations of TGF- $\beta$ and TNF- $\alpha$ may affect Gli2 expression. However, it should first be demonstrated that TNF- $\alpha$ is unable to influence Gli2 expression in HL60 and U937 cells. No significant differences were observed in the level of Gli2 expression in HL60 and U937 cells between the control and TNF- $\alpha$ groups (Fig. 2A and B). Findings of recent studies have reported that TNF- $\alpha$ affected sonic hedgehog through NF- $\mathrm{B}$ (34) and sonic hedgehog affects Gli2 expression. However, Hh receptor molecules (Ptch and Smo) are lost in HL60 and U937 cells (7). This observation may explain the reason for TNF- $\alpha$ not having an impact on Gli2 expression in the HL60 and U937 cells. Furthermore, there was a significant difference in the level of Gli2 expression between HL60 and U937 cells that were treated with TGF- $\beta+\mathrm{TNF}-\alpha$ and those treated with TGF- $\beta$ only (Fig. 2); the Gli2 expression in HL60 cells was decreased (Fig. 2C and E) and Gli2 expression in the U937 cells was lower than that of cells treated with TGF- $\beta$ (Fig. 2D and F). It is possible that the expression of TGF- $\beta$ receptors in the HL60 and U937 cells was increased by TNF- $\alpha$, whereas, TGF- $\beta$ markedly reduced Gli 2 expression.

The mechanism by which TGF- $\beta$ reduces Gli2 expression in HL60 and U937 cells is related to Smad2 or Smad3. As a downstream signaling molecule for TGF- $\beta, \operatorname{Smad} 3$ is thought to contribute most Smad-dependent responses to TGF- $\beta$ in the adult, whereas Smad2 is critical during embryogenesis $(35,36)$. SIS3 was used to inhibit the effect of TGF- $\beta$. Fig. 3 shows that SIS 3 was able to inhibit the effects of TGF- $\beta$ or TGF- $\beta+$ TNF- $\alpha$, which may decrease the Gli2 expression in HL60 and U937 cells. Since Ptch and Smo are not expressed in HL60 and U937 cells (7), this effect is independent from the Ptch/Smo axis. Gli2 induction by TGF- $\beta$ is Smad3-dependent.

We also tested the effect of SIS3 on Gli2 expression in HL60 and U937 cells. As shown in Fig. 4, SIS3 significantly increased the level of Gli2 expression in HL60 (Fig. 4A and C) and U937 cells (Fig. 4B and D). As SIS3 is a specific inhibitor of Smad3, this shows that SIS3 is able to block the TGF- $\beta$ signaling pathway. Since leukemia cells secrete TGF- $\beta$, TGF- $\beta$ produced by HL60 and U937 cells is able to reduce Gli2 expression.

TGF- $\beta$ has been shown to have growth-enhancing and growth-inhibitory properties, the predominant effect being dependent on the particular cell type and other present growth factors $(37,38)$. The effect of TGF- $\beta$ on HL60 and U937 cells in our study was different from that observed in previous studies, which reported that TGF- $\beta$ increased the expression of the $\mathrm{Hh}$ signaling molecule Gli2 in various human cell types, including normal fibroblasts and keratinocytes, as well as various cancer cell lines (3). This difference may be due to the characteristics of different cell lines and the other growth factors present.

In conclusion, as a potent inducer, TGF- $\beta$ reduced Gli2 expression in the U937 cell line. The combination of TGF- $\beta$ and TNF- $\alpha$ decreased Gli2 expression in the HL60 cell line and SIS3 inhibited the effect of TGF- $\beta$. The induction of Gli2 expression is Smad3-dependent. These results show that TGF- $\beta$ functions as a cytokine, which may be capable of reducing $\mathrm{Hh}$ signals in certain types of leukemia cell lines, and indicate new areas of investigation for efficient therapeutic approaches against certain types of leukemia progression. Therefore, further in vivo and in vitro studies are required to identify such therapies.

\section{References}

1. Lum L and Beachy PA: The Hedgehog response network: sensors, switches, and routers. Science 304: 1755-1759, 2004.

2. Lauth M and Toftgård R: Non-canonical activation of GLI transcription factors: implications for targeted anti-cancer therapy. Cell Cycle 6: 2458-2463, 2007.

3. Dennler S, André J, Alexaki I, et al: Induction of sonic hedgehog mediators by transforming grow th factor-beta: Smad3-dependent activation of Gli2 and Glil expression in vitro and in vivo. Cancer Res 67: 6981-6986, 2007.

4. Bhardwaj G, Murdoch B, Wu D, et al: Sonic hedgehog induces the proliferation of primitive human hematopoietic cells via BMP regulation. Nat Immunol 2: 172-180, 2001.

5. Detmer K, Walker AN, Jenkins TM, et al: Erythroid differentiation in vitro is blocked by cyclopamine, an inhibitor of hedgehog signaling. Blood Cells Mol Dis 26: 360-372, 2000.

6. Bai LY, Chiu CF, Lin CW, et al: Differential expression of Sonic hedgehog and Gli1 in hematological malignancies. Leukemia 22: 226-228, 2008.

7. Kobune M, Takimoto R, Murase K, et al: Drug resistance is dramatically restored by hedgehog inhibitors in $\mathrm{CD} 34^{+}$leukemic cells. Cancer Sci 100: 948-955, 2009.

8. Fortunel N, Hatzfeld J, Kisselev S, et al: Release from quiescence of primitive human hematopoietic stem/progenitor cells by blocking their cell-surface TGF- $\beta$ type II receptor in a short-term in vitro assay. Stem Cells 18: 102-111, 2000.

9. Fortunel NO, Hatzfeld A and Hatzfeld JA: Transforming growth factor- $\beta$ : pleiotropic role in the regulation of hematopoiesis. Blood 96: 2022-2036, 2000.

10. Jinnin M, Ihn H and Tamaki K: Characterization of SIS3, a novel specific inhibitor of Smad3, and its effect on transforming growth factor-beta1-induced extracellular matrix expression. Mol Pharmacol 69: 597-607, 2006.

11. Bale AE: Hedgehog signaling and human disease. Annu Rev Genomics Hum Genet 3: 47-65, 2002.

12. Taipale J and Beachy PA: The hedgehog and Wnt signaling pathways in cancer. Nature 411: 349-354, 2001.

13. Duman-Scheel M, Weng L, Xin S and Du W: Hedgehog regulates cell growth and proliferation by inducing Cyclin D and Cyclin E. Nature 417: 299-304, 2002.

14. Lai K, Kaspar BK, Gage FH and Schaffer DV: Sonic hedgehog regulates adult neural progenitor proliferation in vitro and in vivo. Nat Neurosci 6: 21-27, 2003.

15. Bigelow RL, Chari NS, Unden AB, et al: Transcriptional regulation of bcl-2 mediated by the sonic hedgehog signaling pathway through gli-1. J Biol Chem 279: 1197-1205, 2004.

16. Watkins DN, Berman DM, Burkholder SG, et al: Hedgehog signalling within airway epithelial progenitors and in small-cell lung cancer. Nature 422: 313-317, 2003.

17. Spinella-Jaegle S, Rawadi G, Kawai S, et al: Sonic hedgehog increases the commitment of pluripotent mesenchymal cells into the osteoblastic lineage and abolishes adipocytic differentiation. J Cell Sci 114: 2085-2094, 2001.

18. Kasper M, Regl G, Frischauf AM and Aberger F: GLI transcription factors: mediators of oncogenic Hedgehog signalling. Eur J Cancer 42: 437-445, 2006.

19. Bai CB, Auerbach W, Lee JS, et al: Gli2, but not Gli1, is required for initial Shh signaling and ectopic activation of the Shh pathway. Development 129: 4753-4761, 2002.

20. Ikram MS, Neill GW, Regl G, et al: GLI2 is expressed in normal human epidermis and BCC and induces GLI1 expression by binding to its promoter. J Invest Dermatol 122: 1503-1509, 2004.

21. Ruiz i Altaba A: Gli proteins encode context-dependent positive and negative functions: implications for development and disease. Development 126: 3205-3216, 1999.

22. Roberts AB and Sporn MB: Transforming growth factor- $\beta$. Adv Cancer Res 51: 107-145, 1988.

23. Sporn MB, Roberts AB, Wakefield LM and de Crombrugghe B: Some recent advances in the chemistry and biology of transforming growth factor-beta. J Cell Biol 105: 1039-1045, 1987. 
24. Massagué J: How cells read TGF-beta signals. Nat Rev Mol Cell Biol 1: 169-178, 2000.

25. Attisano L and Wrana JL: Signal transduction by the TGF-beta superfamily. Science 296: 1646-1647, 2002.

26. de Caestecker MP, Piek E and Roberts AB: Role of transforming growth factor-beta signaling in cancer. J Natl Cancer Inst 92: 1388-1402, 2000.

27. Piao YF, Ichijo H, Miyagawa K, et al: Latent form of transforming growth factor-beta 1 acts as a potent growth inhibitor on a human erythroleukemia cell line. Biochem Biophys Res Commun 167: 27-32, 1990

28. Chen LL, Dean A, Jenkinson T and Mendelsohn J: Effect of transforming growth factor-beta 1 on proliferation and induction of hemoglobin accumulation in K-562 cells. Blood 74: 2368-2375, 1989.

29. Piacibello W, Severino A, Stacchini A and Aglietta M: Differential effects of transforming growth factor- $\beta 1$ on the proliferation of human lymphoid and myeloid leukemia cells. Haematologica 76: 460-466, 1991.

30. Chen Y, Lu L and Wang L: Study on gene expression of TGF beta 1 and its receptor in leukemia cells and the serum TGF beta 1 level in the patients with acute leukemia. Zhonghua Xue Ye Xue Za Zhi 19: 576-580, 1998 (In Chinese).

31. Keller JR, Jacobsen SE, Dubois CM, et al: Transforming growth factor-beta: a bidirectional regulator of hematopoietic cell growth. Int J Cell Cloning 10: 2-11, 1992.
32. Testa U, Masciulli R, Tritarelli E, et al: Transforming growth factor-beta potentiates vitamin D3-induced terminal monocytic differentiation of human leukemic cell lines. J Immunol 150: 2418-2430, 1993.

33. De Benedetti F, Falk LA, Ellingsworth LR, et al: Synergy between transforming growth factor- $\beta$ and tumor necrosis factor- $\alpha$ in the induction of monocytic differentiation of human leukemic cell lines. Blood 75: 626-632, 1990

34. Kasperczyk H, Baumann B, Debatin KM and Fulda S: Characterization of sonic hedgehog as a novel NF-kappaB target gene that promotes NF-kappaB-mediated apoptosis resistance and tumor growth in vivo. FASEB J 23: 21-33, 2009.

35. ten Dijke P and Hill CS: New insights into TGF- $\beta$-Smad signalling. Trends Biochem Sci 29: 265-273, 2004.

36. Massagué J, Seoane J and Wotton D: Smad transcription factors. Genes Dev 19: 2783-2810, 2005.

37. Roberts AB, Anzano MA, Wakefield LM, et al: Type beta transforming growth factor: a bifunctional regulator of cellular growth. Proc Natl Acad Sci USA 82: 119-123, 1985.

38. Tucker RF, Shipley GD, Moses HL and Holley RW: Growth inhibitor from BSC-1 cells closely related to platelet type beta transforming growth factor. Science 226: 705-707, 1984. 